\title{
A SEGÍTSÉGKÉRŐ VISELKEDÉS ÉS A DEPRESSZIÓ KAPCSOLATA A FIATAL FELNŐTTEK KÖRÉBEN
}

Szerzők:

Almássy Zsuzsanna (PhD)

Debreceni Egyetem (Magyarország)

Somogyi Dominika

Nyíregyházi Egyetem (Magyarország)

Szatmári Ágnes

Nyíregyházi Egyetem (Magyarország)

Első szerző e-mail címe:

almassy.zsuzsanna@ped.unideb.hu

\section{Lektorok:}

\author{
Mohácsi Bernadett (PhD) \\ Debreceni Egyetem (Magyarország) \\ Merza Katalin $(\mathrm{PhD})$ \\ Soproni Egyetem (Magyarország)
}

Almássy Zsuzsanna, Somogyi Dominika és Szatmári Ágnes (2019): A segítségkérő viselkedés és a depresszió kapcsolata a fiatal felnőttek körében. Különleges Bánásmód, 5. (4). 7-19.

DOI 10.18458/KB.2019.4.7

\begin{abstract}
Absztrakt
Háttér és célkitűzés: Az utóbbi évek kutatásaiban a segitségkérő viselkedés egyre nagyobb figyelmet kapott. Jelen tanulmány a segítségkérő viselkedés jellegzetességeire fókuszál, fiatal felnőttek körében. A fiatal felnőttek veszélyeztetettek a mentális betegségek kialakulását tekintve, így a segítségkérő viselkedés hátterében álló tényezők feltárása és megértése fontos. Módszerek: Összesen 228 vizsgálati személy töltötte ki a kérdőívet (átlagos életkor: 22,5 év; $S D=3,29)$. A kérdôív a demográfiai adatokon túl a Beck Depresszió Kérdőív rövidített, 9 itemes változatát, a Gotland Férfi Depresszió Kérdőívet és az Általános Segítségkérő Viselkedés Kérdőívet tartalmazta (személyes és családi problémák témakörben). Eredmények: A nők közelebbi segítségnyújtó személyeket jelölnek meg, mint a férfiak, és hajlamosabbak a partnerüktől segitséget kérni, mint a férfiak. Depressziós tünetek fennállása esetében azok a vizsgálati személyek, akik csak férfi depressziós tünetet mutattak, kevésbé hajlandóak segítségért folyamodni, mint azok, akik nem mutatnak vágóérték feletti depresszió szintet, és mint akik a depresszió hagyományos tüneteit mutatják. Következtetések: Mivel a férfi depressziós tünetek gyakran a bevezető tüneteket jelentik a depresszió kialakulásában, és általában maladaptív megküzdési stratégiák alkalmazásához vezetnek, választ kell adni arra a kérdésre, hogy hogyan lehet növelni a segitségkérő viselkedés mértékét.
\end{abstract}

Kulcsszavak: fiatal felnőtttkor, depresszió, férfi típusú depresszió, általános segítségkérés, segítségkérő viselkedés

Diszciplína: pszichológia 


\section{Abstract}

Background: The concept 'help-seeking behaviour' has gained attention in recent years. Early adults are at risk of developing mental disorders, thus exploring and understanding the background of help seeking delay is very important. This study focuses on help seeking intentions among early adults. Methods: The sample of 228 participants (mean age: 22,5 years; $S D=3,29$ ) filled out the questionnaires. After answering some demographic questions, respondents filled out the shortened version of the Beck Depression Inventory, the Gotland Male Depression Scale and the General Help- Seeking Questionnaire (in connection with personal problem and family problem). Results: Women reported closer potential help providers than men. Women tend to ask for help from intimate partner more frequently than men do. Participants who reported only masculine specific symptoms - which are least likely responses to depression - showed lower rates of help-seeking intentions compared with participants with no depressive symptoms or with classic symptoms of depression. Conclusion: Due to the fact that masculine specific symptoms are usually shown in the beginning of depressive episodes, and go hand in hand with maladaptive coping strategies, professionals have to consider how help- seeking intentions could be increased.

Keywords: early adulthood, depression, male type depression, general help -seeking, help -seeking behaviour

Discipline: psychology

A tanulmány összefoglalja a fiatal felnőttek különböző természetű problémák esetén megmutatkozó segítségkéró viselkedését mint megküzdési mechanizmust. Vizsgálja a segítségkérő hajlandóság jellegzetességeit, annak férfiak és nők között megfigyelhető különbségeit. A vizsgálat kitér a depreszsziós tünetek hagyományos és férfi depressziós tüneteinek mérésére, és bemutatja azok összefüggését a segítségkérő hajlandósággal.

A fiatal felnőttkor olyan időszak, amely vulnerabilitást jelent a mentális betegségek kialakulását tekintve. Az idôszakot a korábbi szakirodalmi adatok alapján egységes fejlódési szakaszként jellemezhetjük, amely napjainkra megváltozott. Jelen tanulmány egy nagyobb vizsgálat egy kisebb részét hivatott bemutatni, amelyben a fiatal felnőttkort a hagyományos értelmezésnek megfelelően az elemzések során egységes idôszakként kezeljük. A teljes vizsgálat kitér a kibontakozó felnőtttkor (18-25) és a korai felnőttkor (26-36) összehasonlító elemzésére is. Jelen munka a terjedelmi korlátai ezt nem teszik lehetôvé, így a segítségkérô viselkedés és a dep- ressziós tünetek jellemzésekor, és az összefüggések bemutatásakor a teljes idôszakot vesszük alapul. Az elméleti hátteret bemutató részben a segítségkéró viselkedés alapdefinícióját, a férfiak és a nők közötti különbségeket, a formális és informális segítségnyújtó rendszerek fogalmait járjuk körbe. Az ezt követô részben a fiatal felnőttkor jellemzése a cél, amelyben kitérünk röviden arra is, hogyan gondolkodunk napjainkban erről a nem homogén idôszakról; bemutatjuk a kríziseket és a veszélyeztetettséget ebben az életkorban. Ezt követően a depressziós tünetekről, a depressziós tünetképzésről és az ebben megfigyelhető esetleges nemi jellegzetességekről írunk. Az elemzés három hipotézis mentén történik. Az adatok bemutatása és megbeszélése zárja a tanulmányt.

\section{A segítségkérő viselkedés}

A segítségkérő viselkedés, olyan megküzdési mechanizmusnak is tekinthető szándékos tevékenységet jelent, amely tudatossággal, a probléma 
elismerésével és annak meghatározásával kezdődik (Lynch, Long és Moorhead, 2018). Jelen tanulmányunkban nem csak a professzionális segítő felkeresését definiáljuk segítségkérő viselkedésként, hanem bármely olyan személyes törekvését is, amikor az egyén a problémáját külső személlyel osztja meg. Annak ellenére, hogy a segítségkérő viselkedést meghatározó tényezők (az ezt elősegító, illetve gátló összetevők) iránti tudományos érdeklődés kifejezett, egységes definíciót nehezen határoz meg a szakirodalom. A mentális problémák kezelése terén az egyik legnagyobb kihívást jelenti, hogy azok az egyének, akiknek segítségre lenne szükségük, hogyan kaphatnák meg ezt (Rickwood és Thomas, 2012).

A segitségkérés formális és az informális formáját különböztethetjük meg. Az első esetben olyan szakemberek bevonásával történik a probléma megoldása, akik jogosultak tanácsadás vagy terápia vezetésére, úgymint orvos, pszichológus, szociális segítő. Az utóbbi csoportba pedig a nem szakmai segítséget nyújtó személyeket sorolhatjuk. Ide tartoznak például a családtagok vagy a barátok (Rickwood és Thomas, 2012).

A segítségkérő viselkedés vizsgálatakor kérdés, hogy milyen okok állnak a segítségkérés elmaradásának hátterében, illetve milyen facilitáló tényezők azonosíthatók. Fiatal felnőttkorban különösen szükséges a segítő beavatkozása, hiszen ez az az idôszak, amikor a mentális betegségek nagyobb valószínúséggel jelennek meg, más életszakaszokhoz viszonyítva. Figyelemreméltóak Lynch, Long és Moorhead (2018) kutatási eredményei, mely szerint a 15 és 24 éves kor közötti öngyilkosságok aránya igen magas. Meg kell határoznunk azokat a háttérben húzódó okokat, amelyek azon esetek mögött állnak, amikor az egyén nem fordul segítségért a probléma fokozódásakor.

Az érzelmek megtagadása és az alacsony fokú pszichológiai tudatosság többnyire szerepet játszik azokban az esetekben, amikor az egyén nem szívesen kér segítséget (Lynch, Long és Moorhead,
2018). Gulliver, Griffiths és Christensen (2010) az alábbi tényezőket sorolja fel, amelyek a segítségkérés elmaradását befolyásolják:

- A szegényes mentális egészségtudat esetén az egyén nem tudja megkülönböztetni egymástól a valódi és a normál belső feszültséget és nem ismeri a rendelkezésre álló, igénybe vehető szolgáltatásokat.

- Az attitúdök és személyes viszonyulások kategória a professzionális segítéshez való negatív viszonyulást továbbá, a szakember véleményében való bizalmatlanságot jelenti. Ebben az esetben a személy úgy véli, hogy a segítő nem tud hozzájárulni a problémája megoldásához, illetve képesnek tartja magát arra, hogy egyedül is meg birkózzon a nehézségeivel.

- Megbélyegzés során az érintettek attól félnek, hogy a közösség a betegségük miatt kirekeszti őket.

A jelenséget kutató szerzôk a segítségkérő viselkedést elősegító tényezőiként tartják számon a korábbi sikeres kezeléseket, a magasabb iskolai végzettséget, a mentális betegség hosszú idejű fennállását és a partner támogatását (Gulliver, Griffiths és Christensen, 2010; Rickwood és tsai, 2005).

\section{Depressziós tünetek és a prevalencia adatok kérdései}

Az érzelemszabályozási nehézségekkel jellemezhető kórképeknél, a prevalenciában a két nem képviselői között jelentős különbségeket mutathatóak ki (például: depresszió, a kényszerbetegség kivételével a szorongásos zavarok, borderline személyiségzavar) (Nolen-Hoeksema, 2012).

A férfiak és a nők depressziója közötti különbségekkel leggyakrabban az előfordulási gyakoriság elemzése során találkozhatunk. A betegség megjelenésében, lefolyásában, a terápiás hatékonyságában tapasztalható markáns különbségek vizsgálatára 
kevesebb figyelem jut annak ellenére, hogy a klinikai megfigyelések és tapasztalatok mellett számos kutatási eredmény is arra hívja fel a figyelmet, hogy a férfiaknak és a nőknek nem ugyanazok a tapasztalataik a depresszió tekintetében (Rochlen, és tsai, 2010).

A depresszió diagnózis nagyarányú prevalencia eltérései a kutatók érdeklődését a lehetséges okok vizsgálata felé fordította. Egyrészt megállapíthatjuk, hogy lehetséges az, hogy a depresszió diagnózisának kritériumai főként a nők depressziós tüneteit fedik le, a férfiak kevesebbszer élik meg depressziójukat ezen tünetek mentén. A férfiak tehát nemcsak kevesebb depressziós tünetről számolnak be, hanem azt részben más tünetek mentén is élik meg (Galasinski, 2008; Kilmartin, 2005; Rutz, 2001; Oliffe és Phillips, 2008).

\section{Férfi típusú depresszió}

A lehetséges eltérő tünettan mellett érvelő kutatók hangsúlyozzák a tünetek megjelenésekor azt, hogy a férfi nemi szerep elvárások a függetlenséget, érzelemmentességet, az érzelmekről való gondolkodás elkerülését, a fizikai erô kifejezését, a versengést írják elő. A férfinak erősnek kell lennie, és érzelmeit el kell rejtenie.

A hagyományos női szerepek inkább összeegyeztethetőek a depresszív álla-pottal. (Cochran és Rabinowitz, 2000, 2003; Real, 1997). Elemzések bizonyítják, hogy a férfiakra jel-lemző depressziós tünetek a nőknél is jellemzőek lehetnek (Almássy és tsai, 2014).

A klasszikus tüneti kép vizsgálata mellett azokkal a depressziós tünetekkel is számolni kell, melyeket a férfiakra speciálisan jellemző tünetekként tartunk számon: időszakosan jelentkező dühkitörések; irritabilitás; impulzivitás; tolerancia szint csökkenés; külvilág felé irányuló agresszió; hosztilis, antiszociális megnyilvánulások; eltúlzott tevékenységek (Cochran és Rabinowitz 2000; 2003; Rihmer és Rutz, 2000).
A depressziós tünetek felismerési nehézségei egyrészt az eltérô tünettanból adódhatnak, másrészt a férfiak azon tulajdonságán alapulhatnak, hogy az erősebbik nem képviselői hajlamosabbak problémáikat, tüneteiket tagadni, és összességében kevesebb tünetről beszámolni (Addis és Mahalik, 2003).

A férfiak segítségkérő viselkedését és ezzel összefüggésben a mentális egészségi állapotát jellemző kutatások fontos információkat szolgáltathatnak a depresszió kutatás területén. A kutatások tanulsága szerint, a férfiak kevésbé hajlamosak segítséget kérni testi és lelki panaszaik enyhítése céljából, életkorra, nemzetiségre és etnikai hovatartozásra való tekintet nélkül (Addis és Mahalik, 2003; Mansfield, Addis és Mahalik, 2003). Azt is megfigyelhetjük, hogy a segitőkkel való együttmúködés szintje a férfiak esetében jelentôsen alacsonyabb, mint a nők esetében (Kennedy, 2001). Jelen vizsgálatban a férfiak és a nők segítségkérő hajlandósága és a férfiak és a nők depressziós tünetei is elemzésre kerülnek.

\section{Fiatal felnőttkor és készülődő felnőttség}

A 18-35 év közötti korosztály kijelölésére azért került sor a vizsgálatban, mert a fiatal felnőttkor vulnerabilitást jelent a mentális betegségek megjelenését tekintve. A korcsoport pedig az újabb irányzatok eredménye szerint nem egységes, hanem további csoportokra bontható.

$\mathrm{Az}$ emberi fejlődés szakaszossága, illetve folytonossága a fejlődéslélektan egyik alapvető kérdése. Azonban, ha a klasszikus elméletalkotókat tekintjük (többek között Freudot vagy Eriksont) szembetűnővé válik, hogy az emberi fejlődésről alkotott szakaszokban való gondolkodás és a szakaszok közötti minőségi eltérések ismerete elengedhetetlen az eltérő korosztályok jellemzőinek bemutatásához. Különösen hangsúlyosak ezek a szakaszok a serdülőkor és a felnőtttkor határán. Erikson (1991) az emberi fejlődést nyolc jól elkülöníthető egységre 
osztotta, az azokban megol-dandó feladatok és krízisek mentén. Míg a serdülőkor legfőbb feladata az identitáskialakítása, a fiatal felnőttkorban az intim, érett, felnőtt kapcsolatok létrehozása a lényeges. A mai, felgyorsult világunkban az eriksoni elmélet helytálló ugyan, de a gyorsan történő változások markáns hatást gyakorolnak az egyéni életutak sajátosságaira, kiváltképpen a felnőttség elérésére.

Robbins és Wilner (2001) azonosították és honosították meg a kapunyitási krízis fogalmát az amerikai fiatalok tapasztalataira alapozva, melyet Arnett (2004) kutatási követtek. A kapunyitási krízist olyan jelenségként írták le, amelyet a 19-25 éves korúak élnek át, hasonló jellegzetességeket mutatva a kapuzárási pánikhoz. A krízisben szenvedők a kiégés tüneteit, depressziót, szorongást és az élet értelmetlenségét élhetik át. Mindezek mellett elbizonytalanodhatnak önmagukban, a pályájukban és az életcéljaikban egyaránt. Mivel a szüleik generációja hasonló nehézségekkel nem szembesült, így elhagyatottnak, mintanélkülinek és tanácstalannak érezhetik magukat annak tekintetében, hogy kihez forduljanak segítségért.

Arnett (2004) kutatásiban alátámasztotta, hogy a kapunyitási krízis létező jelenség, de közel sem olyan intenzív, ahogyan azt előtte leírták, továbbá a vizsgálatai során nyert eredmények alapján egy új fejlődéslélektani szakasz létrehozását kezdeményezte. Az emerging adulthood (készülődő felnőttség) (Lisznyai, 2010) olyan átmeneti életszakaszt jelöl, melyben az egyén már nem gyermek és serdülő, azonban még nem érte el a felnőttséget. Ez az időszak átmenetinek tekinthető, amely különböző nehézségek elé állítja a fiatalt. A társadalmi és gazdasági hatások következtében kitolódik a munkakezdés idôszaka, amelyet megelőz a felsőoktatásban való részvétel. Nem ritka, hogy a szakaszt intenzíven megélő fiatal halogatja, kitolja a diploma megszerzését, amelynek következtében a házasságkötést, családalapítást is későbbi életkorban valósítja meg, mindezek mellett átélve a pályakezdés nehezítettségét is. Az életkori szakasz kritikus jellegének alapján egy öndefiníciós nehézség is megjelenik, mely a fiatal identitásának krízisével is együtt járhat és a párkapcsolati elköteleződését is bonyolíthatja (Elekes, Mikuska, és Komlósi 2018).

Robinson (2016) némileg más aspektusból tekint a korszak kritikus jellegére. Az életkori határok tekintetében nézőpontja hasonló, de némiképpen tágítja azokat. Kutatásai alapján megkülönböztet egy korai és egy késői szakaszt. Míg a korai szakasz az arnetti készülődő felnőttkorral (18-25 év) analóg, és a felnôttkori identitás kialakítását tartja fontos feladatának, addig a korai felnőttkorban (25-35 év) a függetlenség vagy elköteleződés a kritikus kérdéskör.

Arnett (2007) kutatásai arra mutatnak rá, hogy míg a készülődő felnőttség szakaszának átmenetisége nehezítheti a felnőttkori identitás kialakítást, a pár - és a hivatásválasztást, amely megterhelő lehet a fiatal számára, azonban ez az időszak rengeteg pozitívumot és fejlôdési lehetôséget is tartogat az egyén számára.

\section{MÓDSZER}

Jelen vizsgálat célja a segítségkérés iránti hajlandóságot és jellegzetességeket feltárni. A vizsgálat célkitűzései között szerepel azon személyek azonositása, akikhez a fiatal felnőttek fordulnak abban az esetben, ha érzelmi és családi problémákkal néznek szembe. A kutatás további célja a depressziós tünetek feltérképezése a 18-35 éves korosztályban, és a tünetképzés jellegzetességeinek és a segítségkérő viselkedés jellemzőinek az összevetése.

\section{A vizsgálat hipotézisei:}

Hipotézis 1.: A nők és a férfiak különböző személyekhez fordulnak segítségért érzelmi és családi problémáik miatt. A nők inkább használják a közelebbi kapcsolataikat (pl. család, partner) mint a férfiak, és a nők nagyobb valószínűséggel fordulnak professzionális segítőhöz. 
Hipotézis 2.: A férfiak segítségkérési hajlandósága elmarad a nők segítségkérési hajlandóságától mind az érzelmi, mind a családi problémák esetén.

Hipotézis 3.: A depressziós tünetek befolyásolják a segítségkérő viselkedést. A férfi depressziós tünetek megléte csökkent segítségkérési hajlandósággal társul.

\section{Minta}

A kérdőívkitöltők száma $n=234$ fő volt. A vizsgálatba való bekerülés feltétele a 18 és 35 év közötti életkor. Ennek megfelelően egy 18 év alatti és öt 35 év feletti kérdőív kitöltő került kizárásra. A végleges elemszám $n=228$ fő. A vizsgálati személyek életkorának átlaga 22,5 év, $S D=3,29$.

A vizsgálati minta nem szerinti megoszlása a következőképpen alakul: 37,3\% $(n=85)$ férfi kitöltó és $62,7 \%(n=143)$ nő töltötte ki a kérdőívet, és felelt meg a vizsgálati feltételnek.

A nemi megoszlás tekintetében vizsgálati csoport a következőképpen alakult: 36,8 \% ( $n=46$ férfi) és $63,2 \%(n=79)$ nő vett részt a vizsgálatban.

A vizsgálati személyek többsége várost jelölt meg lakhelyéül 71,5\%-ban, kisebb része a mintának faluban él 28,5\%-uk. A vizsgálati személyek 37,3\%-a középfokú végzettséggel rendelkezik, 48,7\%-a jelenleg felsőfokú tanulmányokat végez, 11,4\%-a befejezte a felsőfokú tanulmányait, 2,6\%-a szakmával rendelkezik.

\section{Eljárás}

Az adatgyüjtéshez összeállított kérdőívcsomag online módon és papír-ceruza alapú kérdőív formájában volt elérhetô a vizsgálatban részt vevők számára. A kérdőívek kitöltése önkéntes alapon, anonim módon történt.

A papír-ceruza alapú tesztek kitöltése felsőoktatásban részt vevő hallgatók körében történt.
Az adatelemzés során az SPSS 19.0 (Statistical Package for the Social Sciences) statisztikai programcsomag állt rendelkezésünkre.

\section{Vizsgálati eszközök}

A vizsgálat során használt kérdőívcsomag kitöltése 20-25 percet vett igénybe. A vizsgálati személyek az általános és demográfiai adatokat lekérdező kérdések után standard kérdőíveket és -a vizsgálati kérdésnek megfelelően- a külföldi szakirodalomban fellelhető eszközök magyarra fordított, nem adaptált verzióját töltötték ki. A vizsgálati eszközöknek a vizsgálati kérdés szempontjából releváns kérdései kerültek fordításra. A magyarra nem adaptált kérdőívek reliabilitás vizsgálata megtörtént, amely alapján a kérdőívek felhasználhatósága biztosított. Jelen tanulmány a teljes vizsgálati anyag egy részét mutatja be.

\section{A segitségkéró hajlandóság mérése}

A kérdőívben használt kérdőív alapja az Általános Segítségkérő Viselkedés Kérdőív (General Help-Seeking Questionnaire) (Tulio és Valesquez, 2014). Az eredeti kérdőív által felkínált segítségnyújtók listája a kérdőív szerzőinek megjegyzését alapul véve került kiegészítése, hogy a potenciális segítségnyújtók listáját a vizsgált populációhoz igazítsuk. Az eredeti kérdőív személyes/érzelmi problémák és öngyilkossági gondolatok esetében méri a segítségkérő szándékot.

Jelen vizsgálatban érzelmi és családi problémakört vizsgáltunk, amelyben a segítségkérés megtörténhet. Azért jelöltük ki ezt a két helyzetet, mert a fiatal felnőttkor normatív kríziseihez kívántuk azokat illeszteni.

A kérdőív kitöltői hétfokú Likert-skálán jelölik válaszaikat, amelyek arra vonatkoznak, hogy a listában szereplő személyektől, a felmerülő problémájuk során mennyire jellemzó, hogy segítséget kérnek. 
A kiegészített lista tartalmazza a partneren, a szúk családon, a távoli rokonokon, barátokon túl a szociális segítôt, orvost, pszichológust, vallási, politikai vezetőket és a telefonos segítségnyújtás lehetôségét.

A depresszió mérésére hagyományosan alkalmazott eljárás: Beck Depresszió Kérdöiv (BDI)

Vizsgálatunkban a 9 tételt tartalmazó rövidített Beck Depresszió Kérdő́ivet használtuk. A Beck Depresszió Kérdőív (Kopp és Kovács, 2006) az egyik legelterjedtebb módja a depresszió tüneteinek feltárására. A válaszadónak négy fokú skálán kell megítélnie, mennyire tartja az adott itemet önmagára igaznak. A kérdő́ív itemei a depresszió diagnosztikus kritériumrendszerek által megjelölt tünetekre: alvászavarra, fáradtságra, döntésképtelenségre, munkaképtelenségre, önvádlásra, közönyösségre vonatkoznak. A kérdőív alapján diagnózis nem állítható fel, azonban a vizsgáló eljárás a depresszió súlyosságának megállapítására alkalmas (Kopp és Kovács, 2006).

Férfi depressziós tünetek mérése: Gotland Férfi Depresszió Kérdöiv (Gotland Male Depression Scale-GMDS)

A férfi depressziós tünetek mérésére a Gotland Férfi Depresszió Skálát használtuk (Innamorati és tsai, 2011). A skála 13 itemet tartalmaz. A „hagyományos" depressziós tünetek mellett (reménytelenség érzés, kiégettség, üresség érzése, alvászavarok) a férfi típusú depressziós tüneteket is felméri (alacsonyabb tűréshatár, agresszívebb megnyilvánulások, túlzott aktivitás, fokozott munkavégzés). A kérdőívet azért fejlesztették ki, hogy megnövelje a major depresszió felismerésének valószínűségét azáltal, hogy a jellegzetesen férfiakra jellemző (gyakran a depressziós tünetképzés korai tüneteiként megmutatkozó) tünetekre kérdez rá.

A kérdőív állításait a kitöltők négy fokozatú Likert-típusú skálán értékelik. A férfiakra jellemző tüneti kép mérése a női mintán is lehetséges (Almássy és tsai, 2014). A skála klinikai diagnózis felállítására nem alkalmas, a depresszió súlyosságának megállapítása használatával lehetséges.

\section{EREDMÉNYEK}

\section{A segítségkérés és a potenciális segítség- nyújtók}

Első célkitűzésünkben arra kerestük a választ, hogy az érzelmi és a családdal kapcsolatos problémák esetén kitôl kérnek jellemzően segítséget a vizsgálati személyek. A segítségkérô szituációt érzelmi problémára és családi problémára vonatkoztattuk.

Elemeztük, hogy ki az első öt legvaló-színúbb személy (a tizenkét felkínált lehetôség közül), akihez segítségért fordul az egyén a problémája esetén (1. táblázat). A leíró eredményekből látszik, hogy mind a két problémakör esetén a bizalmas társ, a szülők, a barátok, és a távolabbi családtagok, ismerősök kapják a legnagyobb szerepet.

Elmondhatjuk, hogy a segítségnyújtóként használt legvalószínúbb szereplők között nem találkozunk az orvossal, a pszichológussal, a szociális területen dolgozó segítôvel, a politikai/vallási vezetőkkel. Nem jellemző tehát a mintánkra, hogy professzionális segítőt jelölnének meg olyan személyként, aki segithet megoldani a problémájukat. Az 1. táblázatban bemutatott sorrendiség a férfiak és a nők esetében megegyezik, ezért erre vonatkozó adatokat külön nem közlünk.

\section{Nemi különbségek a segítségkérő haj- landóságban}

Az elemzésnek ezen a pontján a két nem közötti különbségeket vizsgáltuk, és a kérdésünk az volt, hogy mutatkozik- e nemi különbség a két felkínált problémakör esetében a férfiak és nők között abban, hogy milyen mértékben fordulnak segítségért egy-egy személyhez (2. táblázat). 
Mivel adataink nem mutatnak normál eloszlást a segítségkérő viselkedés mutatói tekintetében, nem paraméteres statisztikai eljárásokat használtunk az elemzések során. A csoportok összehasonlítására Mann-Whitney próbát alkalmaztunk.

1. táblázat: A segitségkérés legjellemzőbb személyei (forrás: a Szerzők)

\section{Érzelmi probléma \\ A segítség igénybevételének átlag értéke $(M)$}

$S D$

2,06

1,83

1,78

2,07

1,87

A segítség igénybevételének átlag értéke $(M)$

$S D$

$\begin{array}{ll}5,05 & 2,12 \\ 4,45 & 2,02 \\ 4,73 & 2,06 \\ 3,22 & 2,12 \\ 2,48 & 1,80\end{array}$

2. táblázat: A potenciális segitségnyújtók igénybevételére vonatkozó nemi különbségek (forrás: a Szerzôke)

\begin{tabular}{|c|c|c|c|c|}
\hline \multirow[t]{2}{*}{ Érzelmi probléma } & \multirow[t]{2}{*}{$\begin{array}{l}\text { Szignifikancia } \\
\text { szint }(p)\end{array}$} & \multirow[t]{2}{*}{$\begin{array}{c}\text { Mann-Whitney } \\
U\end{array}$} & \multicolumn{2}{|c|}{$\begin{array}{c}\text { Milyen mértékben } \\
\text { veszi igénybe a } \\
\text { segítséget (rangszám } \\
\text { átlag) }\end{array}$} \\
\hline & & & férfi & nő \\
\hline Bizalmas társ & 0,003 & 4701,0 & 98,31 & 124,13 \\
\hline Szociális segítő & 0,053 & 5480,0 & 121,53 & 110,32 \\
\hline Orvos & 0,007 & 5019,5 & 126,95 & 107,1 \\
\hline Oktató & 0,009 & 4920,5 & 128,11 & 106,41 \\
\hline Politikai/Vallási vezető & 0,012 & 5402,0 & 122,45 & 109,78 \\
\hline Telefonos segélyvonal & 0,014 & 5481,0 & 121,52 & 110,33 \\
\hline \multirow[t]{2}{*}{ Családi probléma } & \multirow[t]{2}{*}{$\begin{array}{l}\text { Szignifikancia } \\
\text { szint }(\not)\end{array}$} & \multirow[t]{2}{*}{$\begin{array}{c}\text { Mann-Whitney } \\
U\end{array}$} & \multicolumn{2}{|c|}{$\begin{array}{l}\text { Milyen mértékben veszi } \\
\text { igénybe a segítséget } \\
\text { (rangszám átlag) }\end{array}$} \\
\hline & & & férfi & nő \\
\hline Telefonos segélyvonal & $p=0,012$ & $U=5448,5$ & 121,9 & 110,1 \\
\hline
\end{tabular}


Eredményeink szerint a nők szignifikánsan magasabb pontszámot jelöltek meg abban a tekintetben, hogy milyen mértékben jellemző, hogy a bizalmas társ felé fordulnának segítségért. A férfiak és a nők összehasonlításakor láthatjuk, hogy a férfiak magasabb pontszámot adnak a professzionális segítőhöz fordulás esetének (való-színúbbnek ítélik annak lehetőségét, hogy használnák probléma esetén), mint a nők. A bizalmas társhoz, és a közvetlen családtagokhoz hasonlítva, a professzionális segítók távolabbi segítségnyújtóként definiálhatók. Szembetűnő adat, hogy a férfiak szignifikánsan nagyobb mértékben mutatnak hajlandóságot a profeszszionális segítőkhöz való fordulás tekintetében, mint a nôk. Elsô hipotézisünket ezek alapján részben tekint-hetjük igazoltnak: a nők és a férfiak segítségnyújtóként legnagyobb mértékben megjelölt személyei nem különböznek sem az érzelmi, sem a családi problémák esetében.

A hipotézis második fele, mi-szerint a nók nagyobb mértékben használják a közelebbi kapcsolataikat, igazolódott.

\section{A segítségkérő viselkedés elutasítása}

Vizsgáltuk, hogy az egyén mennyire képviseli azt az attitűdöt, hogy nem szeret segítségért fordulni senkihez a problémájával. Továbbá azt vizsgáltuk meg, hogy a depressziós tünetek fennállása esetében kihez fordul segítségért az egyén.

A segítség-kérô hajlandóságot ismét érzelmi és családi problémák esetén vizsgáltuk. A segítségkérő viselkedés elutasítása az érzelmi problémák esetében (Mann-Whitney próba alapján) szignifikáns eltérést mutat a két nem képviselői között $(U=5048,500 p=0,027)$.

Érzelmi problémák esetén a férfiak szignifikánsan nagyobb mértékben jelentik ki azt, hogy nem szeretnek segítséget kérni senkitől.

A második hipotézisünket részben tekinthetjük igazoltnak, mivel a családi probléma esetén nem igazolódott a feltevésünk.

\section{A depressziós tünetek és a segítségkérő haj- landóság}

A vizsgálati személyek depressziós tüneteit vizsgálva az alábbi eredményeket kaptuk.

A BDI alapján a minta 82,5 \%-a nem mutat depressziós tüneteket, 17,5 \%-a pedig jelentós mértékủ depressziós tüneteket mutat. A vágóérték feletti depressziós tüneteket mutató 17,5\%-ból a minta 16,2\%-ánál enyhe, 1,3\%-ánál középsúlyos depressziót találtunk.

A GMDS skála alapján férfi depressziós tüneteket mutat a vizsgálati személyek 38,6\%-a. A GMDS alapján a súlyosságot tekintve elmondhatjuk, hogy a vizsgálati személyek 61,4\%-a nem mutat depressziós tünetet, 33,8\%-a enyhe depressziós tünetekről, 4,8\%-a pedig középsúlyos depressziós tünetekről számol be.

- Depressziós tünetek nem detektálhatók (GMDS és BDI-n is tünetmentes): $n=136$ fö (1. csoport)

- Csak hagyományos depressziós tünettel jellemezhetők (GMDS skála nem jelez, BDI skála jelez depressziót): $n=4$ fó (2. csoport)

- Csak férfi depressziós tünetekkel jellemezhetők (GMDS jelez, BDI nem jelez jelentós mértékú depressziót): $n=52$ fó (3. csoport)

- Mind hagyományos, mind férfi depressziós tünetek jelen vannak (GMDS skála és BDI skála is jelez): $n=36$ fó (4. csoport)

Vizsgálati kérdésként merült fel, hogy a különböző depressziós tüneteknek a fennállása és a segítségkérési hajlandóság milyen összefüggéseket mutat. A kialakított 4 vizsgálati csoporthoz tartozó, segítségkérési hajlandóságot vizsgáló adatokat Kruskal-Wallis próbának vetettük alá mind az érzelmi, mind a családi problémák esetén. Érzelmi problémák tekintetében a négy csoport segítségkérési hajlandóságában a következő potenciális segítségnyújtók kapcsán kaptunk szigni-fikáns különbségeket: pszichológushoz $\left[\chi^{2}(3)=22,051\right.$, $p<0,000]$, szociális segítőhöz $\left[\chi^{2}(3)=25,572\right.$, 
KÜLÖNLEGES BÁNÁSMÓD, V.ÉVF. 2019/4.

$p<0,000]$ politikai/vallási vezetőhöz $\left[\chi^{2}(3)=17,931\right.$, $p<0,000]$, telefonos segélyvonalhoz $\left[\chi^{2}(3)=20,977\right.$, $p<0,000]$ való fordulás esetén. A depressziót mutató csoportok között a legkisebb hajlandóságot a 3. csoport mutatja. Vagyis elmond-hatjuk, hogy a kizárólagosan férfi depressziós tüneteket mutató egyének szignifikánsan kisebb mértékben mutatnak segítségkérési hajlandóságot. A vizsgálati csoportok rangszám átlagait a 3. táblázat mutatja be

$\mathrm{Az}$ eredmények alapján elmondhatjuk, hogy a harmadik hipotézisünk teljesült: a férfi depressziós tünetek megtapasztalása kisebb mértékű segítségkérő viselkedéssel társul.

3. táblázat: a segitségkérö viselkedés és a depressziós tünetek vizsgálatakor kapott rangátlagok az érzelmi problémák esetében (forrás: a Szerōook)

\begin{tabular}{lcccc}
\hline \multicolumn{4}{c}{ Potenciális segítségnyújtók } \\
& Pszichológus & Szociális segítő & $\begin{array}{c}\text { Politikai/vallási } \\
\text { vezető }\end{array}$ & $\begin{array}{c}\text { Telefonos } \\
\text { segélyvonal }\end{array}$ \\
\cline { 2 - 5 } & \multicolumn{4}{c}{ rangszám átlagok } \\
\hline 1. csoport & 108,75 & 107,54 & 111,61 & 108,93 \\
\hline 2. csoport & 111,63 & 128,13 & 131,88 & 134,75 \\
\hline 3. csoport & 103,62 & 109,42 & 105,31 & 112,50 \\
\hline 4. csoport & 152,26 & 146,60 & 136,75 & 136,17 \\
\hline
\end{tabular}

Családi probléma esetében a négy csoport segítségkérési hajlandóságában a következő szignifikáns különbségeket figyelhetjük meg a potenciális segítségnyújtók vonatkozásában:

szülők $\left[\chi^{2}(3)=7,641, p=0,054\right]$, nagyszülők $\left[\chi^{2}(3)\right.$ $=8,982, p=0,030]$, pszichológus $\left[\chi^{2}(3)=21,258\right.$, $p<0,000]$, szociális segítő $\left[\chi^{2}(3)=28,924, p<0,000\right]$, orvos $\left[\chi^{2}(3)=23,389, p<0,000\right]$, politikai/vallási vezető $\left[\chi^{2}(3)=32,748, p<0,000\right]$, telefonos segélyvonal $\left[\chi^{2}(3)=22,119, p<0,000\right]$. A vizsgálati csoportok rangszám átlagaita 4. táblázat mutatja be.
A tendencia hasonló mint az érzelmi problémák esetében. A szülők és a pszichológus esetében találunk kis mértékben eltérô mintázatot.

Ezek alapján elmondhatjuk, hogy a szülők kivételével (itt a legkisebb mértékben a 4. csoport valószínűsítette a segítségkérést) a férfi depressziós tüneteket mutatóknak a legalacsonyabb a hajlandósága a segítségkérésre vonatkozóan.

A harmadik hipotézisünket a fentiek alapján igazoltnak tekinthetjük.

4. táblázat: A segitségkérö viselkedés és a depressziós tünetek vizsgálatakor kapott rangátlagok a családi problémák esetében (forrás: a Szerọōk)

\begin{tabular}{cccccccc}
\hline \multicolumn{1}{c}{ Szülők } & Nagyszülők & Pszichológus & $\begin{array}{c}\text { Szociális } \\
\text { segítón }\end{array}$ & Orvos & $\begin{array}{c}\text { Politikai/ } \\
\text { vallási } \\
\text { vezetón }\end{array}$ & $\begin{array}{c}\text { Telefonos } \\
\text { segélyvonal }\end{array}$ \\
\hline & & & \multicolumn{3}{c}{ rangszám átlagok } \\
\hline 1. csoport & 121,50 & 113,93 & 110,36 & 109,13 & 108,82 & 108,26 & 110,43 \\
\hline 2. csoport & 160,00 & 197,25 & 82,50 & 129,88 & 125,75 & 159,13 & 130,00 \\
\hline 3. csoport & 106,02 & 103,28 & 103,32 & 105,31 & 107,40 & 108,95 & 107,45 \\
\hline 4. csoport & 95,25 & 123,68 & 149,86 & 146,38 & 144,97 & 141,14 & 138,35 \\
\hline
\end{tabular}




\section{MEGBESZÉLÉS}

A vizsgálat során feltártuk a segítségkérő hajlandóság jellemzőit fiatal felnőttek körében. Érzelmi, személyes probléma és családi probléma esetében is elmondhatjuk, hogy a professzionális segítôhöz fordulás nem szerepel a leggyakrabban segítő személyként használható személyek között. Ez a jellegzetesség a férfiakra és a nőkre egyaránt igaznak mondható. Ennek okai között a szakirodalmi áttekintésben ismertetett adatok alapján elmondhatjuk, hogy gyakran a szegényes pszichológiai tudatosság, a megbélyegzéstől való félelem is állhat. Az egyén továbbá érezheti azt, hogy képes egyedül megoldani a problémáját, illetve képes azonosítani a környezetében azokat a személyeket, akik megoldást tudnak adni a problémáikra. Ugyanakkor a szakirodalom tájékoztat arról is, hogy ez veszélyes lehet, mert ebben az életkorban a legsérülékenyebbek az egyének a mentális problémák kialakulásával szemben és a maladaptív megküzdési módok rögzülése is ebben az életkorban a legvalószínúbb. Ezek alapján a megfeleló szakember, profeszszionális segító elérése, megkeresése sokszor elengedhetetlen lenne a súlyosabb problémák elkerülése céljából. Bár (a szakirodalmi áttekintésben ismertetett) ku-tatás igazolta, hogy a mentális problémákkal küzdő férfiak vonakodnak professzionális szakembertől segítséget kérni. Vizsgálatunkban a hajlandóság tekintetében ennek az eredménynek részben ellentmondó eredményeket kaptunk. Nem szerepelt a leggyakoribb személyek között egy hivatásos segítő sem, viszont amikor a nőket és a férfiakat hasonlítottuk össze, különbségek igazolódtak. A nők és a férfiak között szignifikáns különbség mutatkozott, amelyből azt látjuk, hogy a nők kevésbé hajlandóak profesz-szionális segítséget kérni, mint a férfiak. További kérdésként merülhet fel, hogy a segítségkérő hajlandóság jelölése, kifejezése után milyen arányban történnek meg a segítségkérések. Valóban megje-lennek-e a férfiak a segítőknél. Jelen vizsgálatban a mentális problémákat a depressziós tünetképzés képviselte, viszont nem tet-tünk különbséget a nők és a férfiak között (a terjedelmi keretek betartása miatt) amely eredmény tovább árnyalná az eredményeket ebben a tekintetben. A férfi típusú depresszió gyakran rejtett marad. Nem diagnosztizálják az egyént, mivel ezek a tünetek elfedik a valódi depressziós tüneteket. A szakirodalom alapján elmondható, hogy a segítség (kérés vagy elfogadás) elmaradása hosszú távon súlyos következményekkel járhat. $\mathrm{Az}$ úgynevezett férfi depressziós tünetek megjelenését azzal ma-gyarázzák, hogy olyan tüneteket él meg az egyén, amely nem azonosítható a gyengeséggel, elesettséggel, inaktivitással. Figyelmet kell fektetni az externalizáló tünetek megjelenésére is.

A férfi depressziós tünetek gyakran a depresszió bevezető fázisában figyelhetôk meg (amely mindkét nem esetében hasonlóan történhet). Az externalizáló tünetek mint az irritabilitás, düh, impulzivitás megjelenése tovább mélyülve, és maladaptív megküzdési módokkal társulva vezethet a súlyosbodáshoz.

Eredményeinkből kitűnik, hogy a segítségkérő viselkedés abban a csoportban a legalacsonyabb, amelybe a kizárólag férfi depressziós tüneteket mutató egyének tartoznak. Ennek oka az lehet, hogy az externalizáló tünetek megjelenése társadalmilag elfogadottabb (fóleg a férfiak körében) így bár a probléma fenn áll, kisebb valószínűséggel keres az egyén megoldást azokra. Amennyiben az általunk mért mindkét depresszió skálán vágópont feletti értéket ért el az egyén, nagyobb valószínűséggel mutat hajlandóságot a segítségkérésre, mint a többi csoport képviselói. A hagyományos és a férfi tünetek megléte feltételezheti a nagyobb fokú szenvedésnyomás meglétét és esetlegesen a könnyebb felismerhetőséget is.

A további elemzéseinkben a depressziós tünetek megjelenése, tünettana, háttértényezői és a segítségkérő hajlandóságban megmutatkozó jellegzetességek részletesebb elemzésére törekszünk a fiatal felnőttkor korcsoport bontásával (készülődő felnőttkor és a korai felnőttkor). 


\section{IRODALOM}

Addis, M. E., \& Mahalik J. R. (2003). Men, masculinity, and the contexts of help seeking. American Psychologist. 58(1), 5-14.

Almássy Zs., Baksa N., Papp G., \& Szemán-Nagy A. (2014): Nemi különbségek vizsgálata a depressziós tünetegyüttesben az alexitímia mentén, különös tekintettel a férfi depresszióra. Magyar Pszichológiai Szemle 69(2), 319 - 336.

Arnett, J.J. (2004). Emerging Adulthood: The Winding Road from the Late Teens Through the Twenties. New York: Oxford University Press.

Arnett, J.J. (2007): Emerging Adulthood: What Is It, and What Is Good for? Child Development Prospectives, 1(2), 68-73.

Cochran, S. W., \& Rabinowitz, F. E. (2000). Men and depression: clinical and empirical perspectives. San Diego: Academic Press.

Cochran, S. W., \& Rabinowitz, F. E. (2003). Gender-sensitive recommendations for assessment and treatment of depression in men. Professional Psychology: Research and Practice. 34(2), 132-140.

Elekes Sz., Mikuska P., \& Komlósi P. (2018): A pályaidentitás, párkapcsolati elköteleződés és családi háttértényezők összefüggései a készülődő felnőttség idején. Alkalmaz̧ott Pszichológia, 18(3), 29-50.

Erikson E.H. (1991). A fiatal Luther és más irások. Budapest: Gondolat Könyvkiadó.

Galasinski, D. (2008). Men's discourses of depression. New York: Palgrave Macmillan.

Gulliver, A., Griffiths, K. M., \& Christensen H. (2010). Barriers and facilities to mental health help-seeking for young elite athletes: a qualitative study. BMC Psychiatry, 12. 157 - 170.

Innamorati, M., Pompili, M., Gonda, X., Amore, M., Serafini, G., Niolu, C., Lester, D., Rutz, W., Rihmer, Z., \& Girardi, P. (2011). Psychometric properties of the Gotland Scale for Depression in Italian psychiatric inpatients and its utility in the prediction of suicide risk. Journal of Affective Disorders. $132(1 / 2), 99-103$.

Kennedy, H. (2001). Do men need special services? Advances in Psychiatric Treatment. 7, 93-99.

Kilmartin, C. (2005). Depression in Men: Communication, diagnosis and therapy. Journal of Men's Health \& Gender. 2(1), 95-99.

Kopp, M., \& Kovács, M. E. (2006). Melléklet: a Hungarostudy 2002 felmérésben használt kérdőívek. In Kopp M., \& Kovács, M. E. (Ed.), A magyar népesség életminösége az ezredfordulón (539550). Budapest: Semmelweis Kiadó.

Lisznyai S. (2010): Készülődő felnőttség. Kutatás a fiatalok mentálhigiénés állapota témakörében. In Puskás-Vajda Zs., Lisznyai, S. (Ed.), Életszakaszok határán. Közösségi és egyéni tanulási feladatok. (9-25). Budapest: FETA Könyvek 5.

Lynch, L., Long, M. \& Moorhead A. (2018): Young Men, Help-Seeking, and Mental Health Services: Exploring Barriers and Solutions. American Journal of Men's Health, 12(1), 138 - 149.

Mansfield, A. K., Addis, M. E., \& Mahalik, J. R. (2003). 'Why don't he go to the doctor?': The psychology of men's health seeking. Internatopnal Journal of Men's Health. 2(2), 93-109.

Nolen-Hoeksema, S. (2012): Emotion Regulation and Psychopathology: The Role of Gender. $A n$ nual Review of Clinical Psychology, 8, 161-187.

Oliffe, J. L., \& Phillips, M. J. (2008). Men, depression and masculinities: A review and recommendations. Journal of Men's Health. 5(3), 194-202.

Real, T. (1997). I don't want to talk about it: Overcoming the secret legacy of male depression. New York: Fireside.

Rickwood, D., Deane, F. P., Wilson, C. J. \& Ciarrochi, J. V. (2005): Young people's help-seeking for mental health problems. Australian e-Journal for the Advancement of Mental Health, 4(3). 1 - 34.

Rickwood, D. \& Thomas, K. (2012): Conceptual measurement framework for helpseeking for 
mental health problems, Psychology Research and Behavior Management, 5. 173-183.

Rihmer Z., \& Rutz, W. (2000). Depresszió és Öngyilkosság férfiaknál. Budapest: Springer Orvosi Kiadó.

Robbins A., \& Wilner A. (2001). Quarterlife Crisis The Unique Challenges of Life in Your Twenties. New York: Penguin Putnam Inc.

Robinson, O. (2016): Emerging adulthood, early adulthood and quarter-life crisis: Updating Erikson for the twenty-first century. In Zukauskiene, R.(Ed.), Emerging adulthood in a European context. (17-30) London and New York: Routledge.
Rochlen, A. B., Paterniti, D. A., Epstein, R. M., Duberstein, P., Willeford, L., \& Kravitz, R. L. (2010). Barriers in diagnosing and treating men with depression: A focus group report. American Journal of Men's Health. 4(2), 167-175.

Rutz, W. (2001). Preventing suicide and premature death by education and treatment. Journal of Affective Disorders. 62(1/2), 123-129.

Tulio, A. P., \&Velaquez, P. A. (2014). Revisiting the General Help Seeking Questionnaire: Adaptation, Exploratory Factor Analysis, and Further Validation in a Filipino College Student Sample. Philipbine Journal of Psychology, 47(1). 1-17. 